\title{
Effect of Ginger on Oxidative Stress Induced by Hydrogen Peroxide in Male Quail
}

\author{
Abdullah F. Abdul-Majeed*1, Saeb Y. Abdul-Rahman², Hassan A. Al-krad ${ }^{3}$

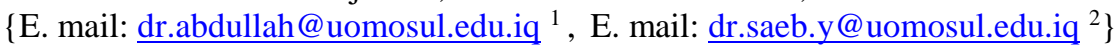 \\ 1,2 Department of Animal Production, College of Agriculture and Forestry, University of \\ Mosul / Iraq, ${ }^{3}$ Department of physiology, College of Vet. Medicine, Hama / Syria.
}

\begin{abstract}
This study was conducted to investigate the effect of Ginger (Zingiber officinale) as an antioxidant and its ability to prevent the effect of $\mathrm{H}_{2} \mathrm{O}_{2}$-induced oxidative stress and its reflections on blood parameters and antioxidant status of male quail. 120 local male quail on 21 days aged were randomly distributed according to complete randomized design into 4 groups and reared until 56 days age as follows: Control group, $\mathrm{H}_{2} \mathrm{O}_{2}$ group (tap water with $0.5 \% \quad \mathrm{H}_{2} \mathrm{O}_{2}$ ), Ginger group (1000 mg ginger/kg ration), $\mathrm{H}_{2} \mathrm{O}_{2}$ with Ginger group (1000 mg ginger $/ \mathrm{kg}$ ration and tap water with $0.5 \% \mathrm{H}_{2} \mathrm{O}_{2}$ ). Results revealed that the $\mathrm{H}_{2} \mathrm{O}_{2}$ induced oxidative stress retracted the blood parameters and serum antioxidant status (decrease glutathione $1.10 \mu \mathrm{mol} / \mathrm{l}$ and increase malondialdehyde $1.79 \mathrm{nmol} / \mathrm{ml}$ ), while the ginger enhanced the blood parameters and serum antioxidants status (elevation glutathione $2.92 \mu \mathrm{mol} / \mathrm{l}$ and decline in malondialdehyde $0.41 \mathrm{nmol} / \mathrm{ml})$ compared to the control group $(1.58 \mu \mathrm{mol} / \mathrm{l}, 0.74$ $\mathrm{nmol} / \mathrm{ml}$ respectively). In conclusion, ginger prevented the oxidative stress effects and returned most of the biochemical values to normal values as in the control group.
\end{abstract}

Keywords: Zingiber officinale, $\mathrm{H}_{2} \mathrm{O}_{2}$, Malondialdehyde, Glutathione, Coturnix coturnix.

\section{Introduction}

Oxidative stress is defined as an imbalance between the production of reactive oxygen species (ROS) and the ability of defensive biological systems (body antioxidants) to remove them or repair their destructive effects [1]. Therefore, the superior production of reactive oxygen species and their free radicals leads to oxidation of poly-unsaturated fatty acids (PUFA) in cellular membranes, thus it disturbs membrane permeability due to lipid peroxidation [2], and formation of the Malondialdehyde (MDA), which is one of its most important products, and it's used as an indicator of cellular membranes damage. The antioxidant systems in the cell work to reduce/or remove the oxidative damage by scavenging those free radicals or inhibiting the process of lipid peroxidation [3].

Many plants has an antioxidant capacity that prevents or reduce the oxidative stress. Ginger (Zingiber officinale) is one of these plants that has antioxidant capacity [4]. The antioxidant effect of ginger is due to its active ingredient as camphene, shogaols, zingiberol, and vitamin $\mathrm{C}$ and $\mathrm{E}[5]$.

* Part of PhD. dissertation submitted by the first author. 
Shanoon [6] has indicated that ginger has an antioxidant effect similar to/ or greater than vitamin $\mathrm{C}$ or E. Al-kattan et al. [7] also indicated that ginger preserves the cells that suffer from oxidative stress whether it is pathologically or chemically induced by $\mathrm{H}_{2} \mathrm{O}_{2}$ with drinking water.

One of the reasons for choosing males in the study is that the males are usually subjected to high level of oxidative stress during spermatogenesis due to the high levels of polyunsaturated fatty acids of spermatozoa membrane [19, 27].

The present study aimed to evaluate the effect of crushed dry ginger roots (Zingiber officinale) role as an antioxidant, and its preventive ability against the hydrogen peroxideinduced oxidative stress.

\section{Materials and Methods}

This study was conducted on 120 male quail (Coturnix coturnix) for the period 21 to 56 days of age. The requirements of lighting, ventilation and temperature were taken into consideration according to the bird's age. The birds were distributed randomly into four groups (30 males/group) in ground cages with dimensions $2.0 \times 2.5 \times 3.0 \mathrm{~m}$ for length, width and height, respectively. Ginger roots (Zingiber officinale) were cleaned, dried and crushed, then it was mixed with the ration at a concentration of $1000 \mathrm{mg} / \mathrm{kg}$, that was formed according to the poultry nutrition requirement [8] and which included a starter ration $(24.6 \%$ crude protein and $2838 \mathrm{kcal} / \mathrm{kg}$ of energy, then replaced with a finisher ration at 42 days aged $(22.00 \%$ crude protein and $2942 \mathrm{kcal} / \mathrm{kg}$ of energy). Water and ration were allowed ad libitum throughout the study. The study treatments were as follows:

$\mathrm{T}_{1}$ : Control group: birds were reared on standard ration and tap water.

$\mathrm{T}_{2}$ : Hydrogen peroxide group $\left(\mathrm{H}_{2} \mathrm{O}_{2}\right)$ : birds were reared on a standard ration and tap water with $0.5 \%$ hydrogen peroxide.

$\mathrm{T}_{3}$ : Crushed ginger group: birds were reared on a standard ration with crushed ginger (1000 $\mathrm{mg} / \mathrm{kg}$ of ration) and tap water.

$\mathrm{T}_{4}$ : Crushed ginger and hydrogen peroxide group: birds were reared on standard ration with crushed ginger $(1000 \mathrm{mg} / \mathrm{kg}$ of ration) and tap water with $0.5 \%$ hydrogen peroxide.

At the end of the study (at 56 days aged), six birds were slaughtered from each group, and the blood was collected in tubes without anticoagulants, then the serum was isolated, and kept at $-20^{\circ} \mathrm{C}$ until biochemical tests were performed, that included determination of serum glucose, cholesterol, triglycerides, Aspartate transaminase (AST), Alanine transaminase (ALT) (Biosystem Kits, Spanish made), serum glutathione GSH level, according to the modified Burtis and Ashwood method [9], and serum MDA level which was estimated by using the modified Thiobarbituric Acid Reaction Assay method [10].

Serum corticosterone hormone level was determined by AssayMax Corticosterone Elisa Kit (manufactured by AssayMax American company), using the ELISA Micro Plate Reader Type Bio-Rad Model 550 (Japanese made).

\section{Statistical analysis:}

Statistical analysis was carried out using the Statistical Analysis Statics program [11]. The experiment was designed according to the complete randomized design (CRD), and the 
data were analyzed by using one-way analysis of variance, and to determine the differences between the means $(\mathrm{P} \leq 0.05)$, we used the Duncan's Multiple Range Test [12], according to researchers Steel and Torrie [13].

\section{Results and Discussion}

Table 1 indicates that the addition of hydrogen peroxide with drinking water $\left(\mathrm{T}_{2}\right)$ led to a significant increase in serum glucose $(338.73 \mathrm{mg} / \mathrm{dl})$ compared to the two groups of ginger $\mathrm{T}_{3}(278.05 \mathrm{mg} / \mathrm{dl})$ and $\mathrm{T}_{4}(308.88 \mathrm{mg} / \mathrm{dl})$, as well as a significant increase in the concentration of cholesterol and triglycerides compared to all study groups at $(\mathrm{P} \leq 0.05)$. These results are in agreement with Salah [14] who said that the addition of $0.5 \%$ hydrogen peroxide in drinking water led to a significant increase in blood glucose in broiler breeder males (Arbor Acers) compared to the control group after 4 and 8 weeks of treatment.

It was found that oxidative stress increases the secretion of corticosterone from the adrenal cortex, which stimulates the gluconeogenesis process [15]. Further, reinforcing this opinion is the presence of a significant increase in the blood corticosterone level of birds of the hydrogen peroxide group (Table 3).

The elevated serum cholesterol when administering hydrogen peroxide may be due to disturbances in the metabolic processes of lipids or in the digestive processes, which led to changes in the absorption and excretion of steroid [16]. This is consistent with what Ameen Agha [17] observed of elevated cholesterol concentration in the group of chickens that consumed $\mathrm{H}_{2} \mathrm{O}_{2}$ with drinking water.

Table 1. Effect of hydrogen peroxide and crushed ginger on blood glucose, cholesterol and triglycerides of male quails at 56 days aged (Means $\pm \mathrm{SE}$ ).

\begin{tabular}{|c|c|c|c|}
\hline Parameters & $\begin{array}{c}\text { Glucose } \\
\text { mg/dl }\end{array}$ & $\begin{array}{c}\text { Cholesterol } \\
\mathrm{mg} / \mathrm{dl}\end{array}$ & $\begin{array}{c}\text { Triglycerides } \\
\text { mg/dl }\end{array}$ \\
\hline $\mathrm{T}_{1}$ (Control) & $320.00 \pm 4.84 \quad \mathrm{AB}$ & $208.35 \pm 8.75 \mathrm{~B}$ & $163.62 \pm 8.31 \quad \mathrm{~B}$ \\
\hline $\mathrm{T}_{2}\left(\mathrm{H}_{2} \mathrm{O}_{2}\right)$ & $338.73 \pm 4.90 \quad \mathrm{~A}$ & $247.68 \pm 7.49 \mathrm{~A}$ & $220.25 \pm 20.70 \mathrm{~A}$ \\
\hline $\mathrm{T}_{3}$ (Ginger) & $278.05 \pm 12.39 \mathrm{C}$ & $166.80 \pm 8.25 \mathrm{C}$ & $122.55 \pm 12.21 \mathrm{~B}$ \\
\hline $\mathrm{T}_{4}$ (Ginger $\left.+\mathrm{H}_{2} \mathrm{O}_{2}\right)$ & $308.88 \pm 4.75 \quad$ B & $221.62 \pm 6.12 \mathrm{~B}$ & $147.72 \pm 13.53 \mathrm{~B}$ \\
\hline
\end{tabular}

The high level of cholesterol in $\mathrm{H}_{2} \mathrm{O}_{2}$-stressed birds may be due to a decrease in the activity of the thyroid gland (Hypothyroidism), as the decrease of the thyroxine in stressed birds has a negative effect on the excretion of cholesterol with the bile, thus increasing its level in the blood [18].

On the other hand, the significant increase in triglycerides was in parallel with the cholesterol increase due to the positive correlation between both parameters [19].

Table 1 also shows the role of crushed ginger $\left(\mathrm{T}_{3}\right)$, which led to a significant decrease $(\mathrm{P} \leq 0.05)$ in the glucose $(278.05 \mathrm{mg} / \mathrm{dl})$ and cholesterol $(166.80 \mathrm{mg} / \mathrm{dl})$ concentration compared to other groups, and the triglycerides $(122.55 \mathrm{mg} / \mathrm{dl})$ compared to the hydrogen peroxide $(220.25 \mathrm{mg} / \mathrm{dl})$ group of quail.

Our results were consistent with the results of Saeid et al. [20] who gave the ginger aqueous extract with drinking water in two concentrations 0.4 and $0.6 \%$ significantly reduced 
glucose level compared to the control group, while the study did not agree with Malekizadeh et al. [21] who indicated in a study on laying hens that dietary addition of ginger powder in 1 and $3 \%$ did not have a significant effect on glucose concentration compared to the control group.

The ability of ginger to reduce blood glucose levels may be due to its phenolic components which classified as hypoglycemic compounds [22], or perhaps due to presence compounds that stimulate insulin secretion, which increases the entry of glucose into the cells and thus leads to a decrease in its level in the blood. This is agreed with Elshater et al. [23] who said that ginger had a significant hypoglycemic effect on blood glucose of alloxaninduced diabetes mellitus compared to the control group.

As for the ability of ginger to reduce the cholesterol and triglyceride levels in the blood, it is in agreement with the findings of Han et al. [24], who stated that it may be due to the inhibition of lipid absorption in the intestine, because the high fiber content of ginger, as well as the oleo-resin compounds [25], which works to inhibit the absorption of bile salts in the intestine, which stimulates the liver to convert cholesterol into new bile salts, which results in a decrease its level in the blood [26].

It was also noted from Table 1 that the addition of ginger with hydrogen peroxide $\left(\mathrm{T}_{4}\right)$ led to reducing the effect of hydrogen peroxide to elevate the level of glucose $(308.88 \mathrm{mg} / \mathrm{dl})$, cholesterol $(221.62 \mathrm{mg} / \mathrm{dl})$ and triglycerides $(147.72 \mathrm{mg} / \mathrm{dl})$, and the values remained at the control group values $(320.00,208.35$ and $163.62 \mathrm{mg} / \mathrm{dl}$ respectively). This is due to the antioxidant activity of ginger, which is returned to the phenolic substances in it [5].

From Table 2 it was noticed that the addition of hydrogen peroxide led to a significant increase in the level of both AST (353.73 U/L) and ALT (12.59 U/L) enzymes in the blood compared to the control group (301.87 and 9.69 $\mathrm{U} / \mathrm{L}$ respectively) at $(\mathrm{P} \leq 0.05)$. This result was in agreement with Taha [27] when he treated broiler breeder males with hydrogen peroxide, and it also agreed with the results of Al-kattan [28], as it recorded a significant increase in both AST and ALT in the blood of laying hens when given $\mathrm{H}_{2} \mathrm{O}_{2}$ in drinking water at $0.5 \%$ concentration compared to the control group.

The high level of AST and ALT in the blood may be attributed to the oxidative stress induced by hydrogen peroxide, which leads to increased cellular oxidative stress, and produce many ROS which oxidizes the polyunsaturated fatty acids in cellular membranes and damage the channels and pumps in it [29], as a result, the membrane loses its selective permeability, due to the lipid peroxidation of the cell membrane and the leaching of these enzymes to the outside of cells [30]. The validity of this assumption is further enhanced by an increase of MDA $(1.79 \mathrm{nmol} / \mathrm{ml})$ level and a decrease in GSH $(1.10 \mu \mathrm{mol} / \mathrm{L})$ level in the blood of quail that were given hydrogen peroxide $\left(\mathrm{T}_{2}\right)$ (Table 3$)$.

Table 2. Effect of hydrogen peroxide and crushed ginger on blood AST and ALT of male quails at 56 days aged (Means \pm SE).

\begin{tabular}{|c|c|c|c|}
\hline Parameters & $\begin{array}{l}\mathrm{AST} \\
\mathrm{U} / \mathrm{L}\end{array}$ & $\begin{array}{c}\mathrm{ALT} \\
\mathrm{U} / \mathrm{L}\end{array}$ & \\
\hline $\mathrm{T}_{1}$ (Control) & $301.87 \pm 9.77 \quad$ B & $9.69 \pm 0,43$ & $\mathrm{BC}$ \\
\hline $\mathrm{T}_{2}\left(\mathrm{H}_{2} \mathrm{O}_{2}\right)$ & $353.73 \pm 16.48 \mathrm{~A}$ & $12.59 \pm 0.63$ & $\mathrm{~A}$ \\
\hline $\mathrm{T}_{3}$ (Ginger) & $246.88 \pm 11.85 \mathrm{C}$ & $8.43 \pm 0.39$ & $\mathrm{C}$ \\
\hline $\mathrm{T}_{4}\left(\right.$ Ginger $\left.+\mathrm{H}_{2} \mathrm{O}_{2}\right)$ & $255.77 \pm 8.84 \quad \mathrm{C}$ & $10.92 \pm 1.02$ & $\mathrm{AB}$ \\
\hline
\end{tabular}

- Different letters in each column indicate a significant difference at $(\mathrm{P} \leq 0.05)$.

$-\mathrm{H}_{2} \mathrm{O}_{2}=0.5 \%$ and Ginger $=1000 \mathrm{mg} / \mathrm{kg}$ of ration . 
As it can be seen from Table 2 that the addition of crushed dry ginger $\left(\mathrm{T}_{3}\right)$ led to a significant decrease in the concentration of both ALT $(246.88 \mathrm{U} / \mathrm{L})$ and AST $(8.43 \mathrm{U} / \mathrm{L})$ enzymes compared to the control group (301.87 and 9.69 U/L respectively). The results of our research are in agreement with Malekizadeh et al. [21] who stated that the addition of ginger powder at 1 and $3 \%$ to the diet has a significant decreasing effect on AST and ALT in the blood of white Leghorn chicken compared to the control group. It also agreed with Shanoon [6] who found a significant decrease in the level of AST and ALT in the blood of broiler breeders when adding 5 and $10 \%$ of the ginger aqueous extract to drinking water compared to the control group.

This may be due to the high level of phenolic compounds in ginger, including Gingerols, Shogaols and Zingerone, which gave ginger its effective role as an antioxidant [31, 32], as well as vitamin $\mathrm{A}$ and $\mathrm{C}$, which leads to the inhibition of the lipid peroxidation. Accordingly, the cell membranes were protected from the oxidation processes, and these membranes retained their selective permeability property, and the cells conserved their contents and not filtered out of the cell, including these enzymes, therefore their level in blood serum decreased [33].

The addition of ginger with hydrogen peroxide $\left(\mathrm{T}_{4}\right)$ prevented the effect of peroxide stress, and this was evident from the decrease of the enzyme levels of AST (255.77 U/L) and ALT (10.92 U/L) compared to the hydrogen peroxide group (353.73 and $12.59 \mathrm{U} / \mathrm{L}$ respectively). This is due to the antioxidant effects of ginger, which that previously mentioned, as well as its lowering effect of the corticosterone level (Table 3).

It is also noticed from Table 3 that the hydrogen peroxide-induced oxidative stress, as it is clear in the significant increase of MDA $(1.79 \mathrm{nmol} / \mathrm{ml})$ and corticosterone $(15.93 \mathrm{ng} / \mathrm{ml})$ (stress hormone) level, and the significant decrease in the level of glutathione $(1.10 \mu \mathrm{mol} / \mathrm{L})$ in the quail blood of $\mathrm{H}_{2} \mathrm{O}_{2}$ - treated group $\left(\mathrm{T}_{2}\right)$ compared to all the study groups.

Table 3. Effect of hydrogen peroxide and crushed ginger on blood Glutathione, Malondialdehyde and Corticosterone of male quails at 56 days aged (Means \pm SE).

\begin{tabular}{|c|c|c|c|}
\hline Parameters & $\begin{array}{l}\text { Glutathione } \\
\text { (GSH) } \\
\mu \mathrm{mol} / \mathrm{L}\end{array}$ & $\begin{array}{c}\text { Malondialdehyde } \\
\text { (MDA) } \\
\mathrm{nmol} / \mathrm{ml}\end{array}$ & $\begin{array}{c}\text { Corticosterone } \\
\mathrm{ng} / \mathrm{ml}\end{array}$ \\
\hline $\mathrm{T}_{1}$ (Control) & $1.58 \pm 0.06 \mathrm{C}$ & $0.74 \pm 0.04 \mathrm{~B}$ & $2.54 \pm 0.12 \mathrm{C}$ \\
\hline $\mathrm{T}_{2}\left(\mathrm{H}_{2} \mathrm{O}_{2}\right)$ & $1.10 \pm 0.04 \mathrm{D}$ & $1.79 \pm 0.12 \mathrm{~A}$ & $15.93 \pm 0.77 \mathrm{~A}$ \\
\hline $\mathrm{T}_{3}$ (Ginger) & $2.92 \pm 0.13 \mathrm{~A}$ & $0.41 \pm 0.05 \mathrm{C}$ & $1.52 \pm 0.18 \mathrm{C}$ \\
\hline $\mathrm{T}_{4}\left(\right.$ Ginger $\left.+\mathrm{H}_{2} \mathrm{O}_{2}\right)$ & $2.00 \pm 0.09 \mathrm{~B}$ & $0.74 \pm 0.05 \mathrm{~B}$ & $4.56 \pm 0.57 \mathrm{~B}$ \\
\hline
\end{tabular}

- Different letters in each column indicate a significant difference at $(\mathrm{P} \leq 0.05)$.

$-\mathrm{H}_{2} \mathrm{O}_{2}=0.5 \%$ and Ginger $=1000 \mathrm{mg} / \mathrm{kg}$ of ration.

Pravda [34] and Ayed et al. [35] stated that hydrogen peroxide depletes the glutathione in the blood and tissues and causes a decrease in its level in the body and that its decrease is associated with an increase in the level of malondialdehyde, which is considered one of the main indicators of the occurrence of the lipid peroxidation. This finding was in line with ALMa'atheedi and Hassan [36] in their study on adult roosters exposed to oxidative stress, and Taha [27] who reported that the addition of hydrogen peroxide to drinking water at $0.5 \%$ of broiler breeder males led to a significant increase in malondialdehyde level, and a significant decrease in the glutathione level in testicular tissue compared to the control group, also was referring to that by Ameen Agha [17] in broilers. 
The elevation of corticosterone level in the $\mathrm{H}_{2} \mathrm{O}_{2}$ group $\left(\mathrm{T}_{2}\right)$ (Table 3 ) in response to stress induced by $\mathrm{H}_{2} \mathrm{O}_{2}$. This is consistent with Abdul-Majeed [15] who said that the oxidative stress induced by $\mathrm{H}_{2} \mathrm{O}_{2}$ leads to an increase in the secretion of the corticosterone (Stress hormone) from the adrenal cortex in response to stress and mentioned that the hydrogen peroxide with drinking water led to a significant increase in corticosterone level of quail compared to the control group at $(\mathrm{P} \leq 0.05)$.

It is also evident from Table 3 that the dietary addition of ginger $\left(\mathrm{T}_{3}\right)$ improved and significantly increased serum glutathione level $(2.92 \mu \mathrm{mol} / \mathrm{L})$ compared to the control group $(1.58 \mu \mathrm{mol} / \mathrm{L})$, and with the other study groups at $(\mathrm{P} \leq 0.05)$. And when ginger was given with hydrogen peroxide $\left(\mathrm{T}_{4}\right)$, it was able to prevent the effect of stress caused by hydrogen peroxide and improve the serum antioxidant status, as it raised the level of glutathione significantly $(2.00 \mu \mathrm{mol} / \mathrm{L})$ compared to both groups of hydrogen peroxide and control (1.10 and 1.58 $\mu \mathrm{mol} / \mathrm{L}$ respectively).

And in regard to MDA, it was significantly decreased when ginger was added to the feed $\left(\mathrm{T}_{3}\right)(0.41 \mathrm{nmol} / \mathrm{ml})$ compared to the control group $(0.74 \mathrm{nmol} / \mathrm{ml})$ and the other study groups at $(\mathrm{P} \leq 0.05)$, and it was at the level of its values in the control group when ginger was added with hydrogen peroxide $\left(\mathrm{T}_{4}\right)(0.74 \mathrm{nmol} / \mathrm{ml})$. Ginger was able to prevent the effect of stress-induced by hydrogen peroxide and returned the MDA values to the level of its values in the control group, and it was even significant with the hydrogen peroxide group at $(\mathrm{P} \leq 0.05)$ (Table 3).

Our results are agreed with Ogbuewu et al. [37] who indicated that ginger acts to protect the cells because it contains gingerols and shogaols that play an essential role in protecting cells from oxidative damage resulting from the free radicals. Also, our results agree with the results of researcher Shanoon [6] who found a decrease in the level of malondialdehyde and an increase in the level of glutathione in the groups of broiler breeder chickens that consumed a diet containing $2.5 \mathrm{~g}$ ginger/ $\mathrm{kg}$ of feed compared to the control group.

The ability of the ginger plant to raise the level of glutathione and reduce the level of malondialdehyde is consistent with all of the Tohma et al. [38], Zidan et al. [39] and Zhang et al. [40] when they indicated that the ginger is one of the plants that possess an antioxidant capacity due to its high phenolic contents. Also, the ginger's ability in decreasing corticosterone may be related to its vitamin $\mathrm{C}$ content which inhibits 11- $\beta$ Hydroxylase and 21-Hydroxylase, so it reduces corticosterone production by the adrenal cortex [19].

To confirm the validity of this assumption, when was given the ginger alone $\left(\mathrm{T}_{3}\right)$, it reduced or decreased the level of the stress hormone (corticosterone) $(1.52 \mathrm{ng} / \mathrm{ml})$ than it was in the control group $(2.54 \mathrm{ng} / \mathrm{ml})$, and when it was added with the hydrogen peroxide $\left(\mathrm{T}_{4}\right)$ $(4.56 \mathrm{ng} / \mathrm{ml})$, there was a significant decrease in its level compared to the hydrogen peroxide group $\left(\mathrm{T}_{2}\right)(15.93 \mathrm{ng} / \mathrm{ml})$, because it reduced and suppressed the effect of stressful hydrogen peroxide and raised the level of the corticosterone hormone (Table 3 ).

\section{Conclusion}

We conclude, our study revealed that the hydrogen peroxide was heavily impacting on all of the studied parameters of the blood, and the addition of a substance that has an antioxidant capacity as ginger (Zingiber officinale) prevented the negative effects of oxidative stress induced by hydrogen peroxide, also that the ginger has an ability or role to improve or enhance the antioxidant status in the body, and returned most of the parameter values and antioxidant status to their values in the control group. 


\section{Acknowledgments}

The authors thanks specially the University of Mosul and the College of Agriculture and Forestry for their assistance and support to carrying out this research.

\section{Conflict of Interest}

The authors declare that there are no conflicts of interest regarding the publication of this manuscript.

\section{References}

[1] Pizzino G, Irrera N, Cucinotta M, Pallio G, Mannino F, Arcoraci V, Squadrito F, Altavilla D, Bitto A. Oxidative Stress: Harms and Benefits for Human Health. Oxid. Med. Cell. Longev., 2017, ID 8416763, 13 pages, https://doi.org/10.1155/2017/8416763

[2] Gianazza E, Brioschi M, Martinez Fernandez A, Casalnuovo F, Altomare A, Aldini G, Banfi C. Lipid peroxidation in atherosclerotic cardiovascular diseases. Antioxid. Redox Signal., 2021 Jan 1;34(1):49-98. https://doi.org/10.1089/ars.2019.7955

[3] El-Beltagi HS, Mohamed HI. Reactive oxygen species, lipid peroxidation and antioxidative defense mechanism. Not Bot Horti Agrobot Cluj Napoca. 2013, 41(1):44-57. https://doi.org/10.15835/nbha4118929

[4] Mbaveng AT, Kuete V. Zingiber officinale. InMedicinal Spices and Vegetables from Africa 2017 Jan 1 (pp. 627-639). Academic Press. https://doi.org/10.1016/B978-0-12-809286-6.00030-3

[5] Mao QQ, Xu XY, Cao SY, Gan RY, Corke H, Li HB. Bioactive compounds and bioactivities of ginger (Zingiber officinale Roscoe). Foods. 2019; 8(6):185. https://doi.org/10.3390/foods8060185

[6] Shanoon AK. Effect of Ginger Zingiber officinale and Thyme Thymus vulgaris on Reproductive and Reproduction performance of broiler breeder chickens Ross 308 (Doctoral dissertation), College of Agriculture, University of Tikrit, Tikrit: Iraq. 2011.

[7] Al-Kattan M, Al-Annaz R, Al-Sarrag I. Effect of Zingiber officinale plant and $\mathrm{H}_{2} \mathrm{O}_{2}$ on some physiological, histological and biochemical parameters in local male rabbits. Mesopotamia J. of Agric. 2007, 35(1):36-42. http://dx.doi.org/10.33899/magrj.2007.26468

[8] Dale N. National research council (NRC). Nutrient requirements of poultry-ninth revised edition (1994). J Appl Poult Res. 1994, 3(1):101. https://doi.org/10.3382/japr.2014-00980

[9] Gault VA, McClenaghan NH. Tietz textbook of clinical chemistry and molecular diagnostics. Elsevier Saunders, Missouri, USA; 2006.

[10] Buege JA, Aust SD. [30] Microsomal lipid peroxidation. In Methods in Enzymology 1978, 52:302310. Academic press, London. https://doi.org/10.1016/S0076-6879(78)52032-6

[11] Statistical Analysis Systems (SAS) Institute. Software, SAS User's Guide: Version 9.2 Review Edition. SAS Institute Inc, Cary, North Carolina, USA. 2008.

[12] Duncan DB. Multiple range and multiple $F$ tests. Biometrics. 1955 Mar 1;11(1):1-42. https://doi.org/10.2307/3001478

[13] Steel RG and Torrie JH. Principles and procedures of statistics. McGraw- Hill Book. Co., Inc., New York. 1960, Pp 481.

[14] Salah SI. Effect of using Vitamin C, A and Fenugreek seeds on some physiological and histological parameters of male Arber Acers Breeder (MSc Thesis) College of Agriculture and Forestry, University of Mosul, Mosul, Iraq. 2008.

[15] Abdul-Majeed AF. Effect of $\mathrm{H}_{2} \mathrm{O}_{2}$-Induced Oxidative Stress, Ginger and Vitamin $\mathrm{C}$ on the Antioxidant Level, Physiological and Productive Performance of Quail and its Progeny (Doctoral dissertation, Ph. D Thesis). College of Agriculture and Forestry, University of Mosul, Mosul: Iraq. 2013,37-39. https://orcid.org/0000-0001-7331-9969 
[16] Hassan SM, Al-Kennany ER, Al-Hafez HA. Hydrogen peroxide-induced atherosclerosis in chickens: effect of vitamin C. Iraqi J. Vet. Sci.. 2000;13(2):249-70. https://www.cabdirect.org/cabdirect/abstract/20003002291

[17] Ameen Agha, FKhT. Effects of Coriander, Thyme, Vanadyl Sulfate and Sodium Tungstate and Their Interactions on Some Physiological and Biochemical Aspects in Broiler Chickens. (Doctoral dissertation, Ph. D Thesis). College of Veterinary Medicine, University of Mosul, Mosul: Iraq. 2002. https://orcid.org/0000-0003-0616-2177

[18] Duntas LH, Brenta G. A renewed focus on the association between thyroid hormones and lipid metabolism. Front. Endocrinol. 2018 Sep 3;9:511. https://doi.org/10.3389/fendo.2018.00511

[19] Abdul-Majeed, AF., AL-Krad, HA, Abdul-Rahman, SY. Effect of Zingiber, Vitamin C and Hydrogen Peroxide on Some Physiological and Productive Parameters in Male Quails. AL-Furat University Journal for Researches and Scientific Studies. 2013, 7(25),218-242. http://journal.alfuratuniv.edu.sy/downloads/files/1549064891_12.pdf

[20] Saeid JM, Mohamed AB, AL-Baddy MA. Effect of aqueous extract of ginger (Zingiber officinale) on blood biochemistry parameters of broiler. Int. J. Poult. Sci.. 2010; 9(10):944-7. https://dx.doi.org/10.3923/ijps.2010.944.947

[21] Malekizadeh M, Moeini MM, Ghazi S. The effects of different levels of ginger (Zingiber officinale Rosc) and turmeric (Curcuma longa Linn) rhizomes powder on some blood metabolites and production performance characteristics of laying hens. J. Agric. Sci. Technol. 2012;14(1):127-134 https://www.sid.ir/en/journal/ViewPaper.aspx?id=283764

[22] Khazaei MR, Makalani F, Ghanbari E, Fayzemahdavi M, Khazaei M. An overview of effective herbal and antioxidant compounds on diabetes. J. Contemp. Med. Sci.. 2018 Sep 26;4(3):126-133. http://www.jocms.org/index.php/jcms/article/view/450/240

[23] Elshater AE, Salman M, Moussa M. Effect of ginger extract consumption on levels of blood glucose, lipid profile and kidney functions in alloxan induced-diabetic rats. Egyptian Academic Journal of Biological Sciences. A, Entomology. 2009 Jun 1;2(1):153-62. https://dx.doi.org/10.21608/eajbsa.2009.15515

[24] Han LK, Gong XJ, Kawano S, Saito M, Kimura Y, Okuda H. Antiobesity actions of Zingiber officinale Roscoe. Yakugaku zasshi: J. Pharm. Soc. Jpn. 2005 Feb 1;125(2):213-7. https://pubmed.ncbi.nlm.nih.gov/15684576/

[25] Srinivasan K. Ginger rhizomes (Zingiber officinale): A spice with multiple health beneficial $\begin{array}{lllll}\text { potentials. } & \text { Pharma } & \text { Nutrition. } & 2017 & \text { Mar } \\ \text { 1;5(1):18-28. }\end{array}$ https://doi.org/10.1016/J.PHANU.2017.01.001

[26] Cohen DE. Balancing cholesterol synthesis and absorption in the gastrointestinal tract. J. Clin. Lipidol. 2008 Apr 1;2(2):S1-3. https://www.ncbi.nlm.nih.gov/pmc/articles/PMC2390860/

[27] Taha, AT. Effect of Some Antioxidant on Reproductive and Physiological Performance in Broiler Breeder Males. (Doctoral Dissertation), College of Agriculture and Forestry, University of Mosul, Mosul: Iraq.2008.

[28] Al-kattan, MMD. Effect of Using Some Antioxidants on Production Performance and Some Physiological Characters in Laying Hens. (Doctoral Dissertation), College of Agriculture and Forestry, University of Mosul, Mosul: Iraq. 2006.

[29] Walia M, Kwan CY, Grover AK. Effects of free radicals on coronary artery. Medical Principles and Practice. 2003;12(1):1-9. https://doi.org/10.1159/000068159

[30] Catalá A, Díaz M. Impact of lipid peroxidation on the physiology and pathophysiology of cell membranes. Front. Physiol. 2016 Sep 22;7:423. https://doi.org/10.3389/fphys.2016.00423

[31] Sekiwa Y, Kubota K, Kobayashi A. Isolation of novel glucosides related to gingerdiol from ginger and their antioxidative activities. J. Agric. Food Chem. 2000 Feb 21;48(2):373-7. http://dx.doi.org/10.1021/jf990674x

[32] Zancan KC, Marques MO, Petenate AJ, Meireles MA. Extraction of ginger (Zingiber officinale Roscoe) oleoresin with $\mathrm{CO} 2$ and co-solvents: a study of the antioxidant action of the extracts. J. Supercrit. Fluids. 2002 Sep 1;24(1):57-76. https://doi.org/10.1016/S0896-8446(02)00013-X 
[33] Al-Katib SM, Al-Khashab EM, Kalo MS, Hamdoon AA. The Antioxidant Effects of Flavonoids and non Flavonoid Part Extracted from Ginger (Zingiber officinale) Roots. Rafidain journal of science. 2009 Sep 1;20(6):18-31. http://dx.doi.org/10.33899/rjs.2009.39940

[34] Pravda J. Hydrogen peroxide and disease: towards a unified system of pathogenesis and therapeutics. Molecular Medicine. 2020 Dec;26(1):1-0. https://doi.org/10.1186/s10020-020-00165-3

[35] Ayed HS, Khalaf AS, Mohammed TM. Effect of Aqueous Extract of Truffle on Some Antioxidants in Rats Exposed to Oxidative Stress induced by Hydrogen peroxide. In IOP Conference Series: Earth and Environmental Science, Volume $735,2^{\text {nd }}$ Virtual International Scientific Agricultural Conference 21-22 January 2021, Iraq. Pp 1-6. https://iopscience.iop.org/article/10.1088/1755$1315 / 735 / 1 / 012019 / \mathrm{pdf}$

[36] AL-Ma'atheedi, MS and Hassan, AA. Effect of vitamin c and selenium on some physiological and reproductive characters in adult roosters exposed to oxidative stress induced by hydrogen peroxide.

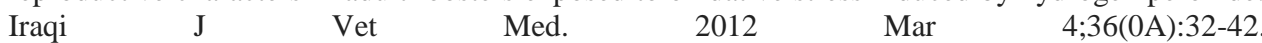
https://jcovm.uobaghdad.edu.iq/index.php/Iraqijvm/article/view/352

[37] Ogbuewu IP, Mbajiorgu CA, Okoli IC. Antioxidant activity of ginger and its effect on blood chemistry and production physiology of poultry. Comp. Clin. Path. 2019; 28(3):655-60. https://doi.org/10.1007/s00580-017-2536-X

[38] Tohma H, Gülçin İ, Bursal E, Gören AC, Alwasel SH, Köksal E. Antioxidant activity and phenolic compounds of ginger (Zingiber officinale Rosc.) determined by HPLC-MS/MS. J. Food Meas. Charact. 2017 Jun;11(2):556-66. https://doi.org/10.1007/s11694-016-9423-Z

[39] Zidan DE, Kahilo KA, El-Far A, Sadek KM. Ginger (Zingiber officinale) and thymol dietary supplementation improve the growth performance, immunity and antioxidant status in broilers. Glob. Vet. 2016;16(6):530-8. https://www.idosi.org/gv/gv16(6)16/3.pdf

[40] Zhang GF, Yang ZB, Wang Y, Yang WR, Jiang SZ, Gai GS. Effects of ginger root (Zingiber officinale) processed to different particle sizes on growth performance, antioxidant status, and serum metabolites of broiler chickens. Poult. Sci. 2009 Oct 1;88(10):2159-66. https://doi.org/10.3382/ps.2009-00165 